Historic, Archive Document

Do not assume content reflects current scientific knowledge, policies, or practices. 



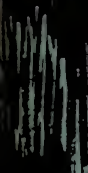

mo

d)

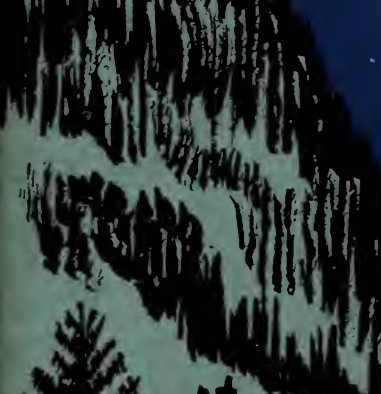

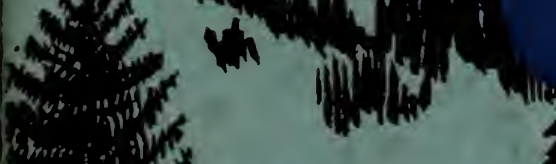

(4)

,

4

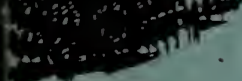

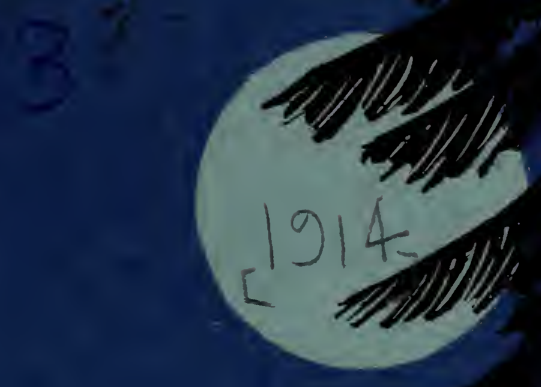




\section{REVISED EDITION}

\section{Of \\ The Forest Planters Guide}

Compiled by

\section{THE D. HILL NURSERY CO., Inc.,}

DUNDEE, ILLINOIS, U. S. A.

Founded 1855

\section{Evergreen Specialists Largest Growers in America}

\section{About Ourselves}

Over fifty years ago, in 1855 , William Hill, uncle to D. Hill, his successor, established a small nursery. From this beginning our nurscries have grown bit by bit until several hundred acres of the surrounding land has been acquired and is now used for the propagation of evergreen and deciduous seedlings and transplants.

Altho incorporated in 1910 it is under the active management of $D$. Hill, who is President and General Manager.

From the first a specialty has been made of the propagation of young evergreen and deciduous stock for forestry planting. Little was known concerning the operations connected with the growing of tree seedlings, and consequently the first few years were spent in experiments and in learning the fundamentals. As years went by, however, knowledge was gained, and little by little, through lessons instilled by disastrous losses, and through wrong methods, a vast fund of knowledge has been obtained.

Eternal vigilance and painstaking attention to detail is the price of success in the growing of tree seedlings.

We realize that the cost of this forest-planting material is, from the view-point of the planter, a most important one. It partly decides the question of whether his tree-planting investment will be profitable or not. Our policy in the past has been, and in the future, will be to grow this class of stock and sell it at the lowest possible price. 


\section{The Forest Planters Guide}

\section{Necessity for New Forests}

On account of the increased interest in forestry that is shown by the numerous inquiries which come to us daily, we have been prompted to publish a small guide as an aid to those interested in reforestation or timber tree planting. Many interested in forestry have repeatedly requested us to publish such a guide, and we recognize that it will assist iil fully answering a great many technical questions inquirers are constantly asking us.

While it is necessary to give a detailed account of many operations, we do not propose to treat exhaustively the vast domain of sylviculture, the laying out of plantations and so forth. Our remarks are intended to be useful more especially to those who are not in position to employ a trained forester, or to obtain expert advice.

It must be admitted that there is an increased recognition of the great importance of forestry and increased interest in planting timber in particular. This is proven by statistics and by the steadily increasing demand for planting material.

Modern forestry in science and practice is the child of necessity. For many years, people have been content to receive from the forest what it offered in abundance, viz:-wood, game, pasture and water-holding, and these were considered as natural and not over-valuable gifts of Providence-the property of whoever thought fit to use them. However, during recent years, the demands have increased to such an extent as to make the plainest intelligence realize that at the present rate of consumption of timber, the supply inevitably will fail unless new timber is planted and grown faster than natural agencies have produced it up to this time.

In the past, wide areas have been denuded by felling all the timber, leaving the soil impoverished by the abstraction of leaf litter, maltreated for the sake of pasture, and left open so that great erosion takes place. In modern times, however, there is a strong tendency to grasp the importance of forests with respect to climate, hygiene and national economy.

In Europe, especially in France and Spain, reckless deforestation has led to the actual abandonment of whole districts. France was forced in the years 1860-64 to pass a law for the compulsory reforesting of mountains, in order to prevent the population of those districts from becoming destitute. Having in view momentary interests only, and quite regardless of consequences, people had used the mountain land for grazing, vegetation was destroyed by drought, and in times of heavy rain the fertile soil was washed into the valleys, so that large tracts were rendered unproductive, and positively injurious, because they increased the danger of devastation from floods and exercised a noxious influence upon the climatic conditions.

Since in forestry the seed time and harvest are so far removed from each other, a lifetime is necessary to repair the consequences of such blunders. Nistakes made at planting have to be atoned for in a similar 
manner; and, however simple forest management may appear at first, it is rendered difficult by the fact, more than any other kind of production, it has to rely largely upon the forces of nature. Human activity is restricted to the planting and care of the trees.

Forests depend for their support upon the same naturai laws as fields and meadows, but with the difference that forests must themselves maintain the fertility of the soil and supply the plant food which they require. An artificial supply of manure is not necessary in well-tended forests, for the soil is enriched by the fallen leaves and needles, and the roots, penetrating far into the ground, open up the deeper layers to chemical and physical disintegration to a much greater extent than plants commonly grown on cultivated land.

Trees draw comparatively little nutrition from the soil-scarcely one thousandth of one per cent of potash and phosphoric acid, while in the case of agricultural crops it is one per cent. The large quantities of carbon required for the formation of wood fiber, are taken from the air; and, further, the humus has a considerable capacity for absorbing gases (ammonia and so forth), while the mineral matter drawn from the soil falls again with the leaves and needles. With all this taken into consideration, we have a natural explanation of the process of the self-manuring and soil-improvement that operates in forests.

In forests of mixed varieties plant food is better utilized because one species requires perhaps just the material which is unnecessary for another; further, the humus becomes in its composition much more varied; the danger of an impenetrable layer of hardpan decreases; and destruction by insects and injury resulting from forest fires is lessened.

On the other hand, it is quite true that a mixed forest requires more careful supervision and causes greater difficulties in thinning, because the development of the various species must be taken into account, and the species which predominate and are of the least value must be checked in favor of those more profitable but of slower growth, and so forth.

As we already have mentioned recognition of the great importance of forests, especially among land-owning corporations and individuals, is increasing rapidly. People are beginning to see that, apart from purely financial and economic considerations, there are social and ethical motives of pressing importance that ought to influence us in promoting forestry. All barren tracts and waste land, of which there are many million acres in the United States, should be reforested and thus rendered productive; and in existing forests the production should be maintained by proper replanting and cutting.

Every delay in planting means a loss of interest, for cultivation is a constantly increasing investment, which will be profitable without any further appreciable cost and which, sooner or later, will yield a very high divident. This is especially the case if we consider the increased value of property when in forest, and the improvement in productiveness of adjacent land, for it has been repeatedly demonstrated that forests increase the yield of crops by tempering the winds and reducing the evaporation of moisture, both of which are important factors in successful farming.

If we read statistics and try to realize the inestimable treasures which are stored in well-regulated forests, as well as the climatic benefits of these tracts in regard to temperature and rainfall, each one of us must feel it his duty to lend a helping hand in the developing and enlarging o 1 this possession of all who live in our country. 


\section{A Brief History of Forestry in the United States}

Nore than a hundred years ago, in 1795 , a committee of the Society for the Promotion of Agriculture, Arts and Manufactures in New York made a report on the best way to preserve and increase the growth of timber. Four years afterwards Congress appropriated $\$ 200,000$ for the purchase and preservation of timber lands to supply ship timbers for the Navy, and in 1822, with the same object in view, it authorized the President to employ the Army and Navy to protect and preserve the live oak and red cedar timber of the Government in Florida. Since that time more and more attention has been given to the forests. In 1828 Governor DeWitt Clinton, of New York, spoke of the reproduction of our woods as an object of primary importance, and in the same year the Government began an attempt to cultivate live oak in the South for the use of the Navy. Three years later an act was passed which is still almost the only protection for the much-abused forests of the public domain.

In 1872 the Yellowstone National Park was established, and in 1873 Congress passed the timber-culture act, which gave Government land in the treeless regions to whoever would plant one-fourth of his claim with trees. In 1875, the American Forestry Association was formed in Chicago through the efforts of Dr. John A. Warder, who was one of the first men to agitate forest questions in the United States. In the centennial year (1876) Dr. Franklin B. Hough, perhaps the foremost pioneer of forestry in America, was appointed special agent in the Department of Agriculture. This was the beginning of educational work in forestry at Washington. Soon afterwards $C_{8}$ ngress began to make appropriations to protect the public timber, but nothing was done to introduce conservative forest management.

About this time forest associations began to be established in the different states, the most influential and effective of which has been that in Pennsylvania. The states also began to form forest boards or commissions of their own.

In 1888 the first forest bill was introduced in Congress. It failed to pass, but in 1891 an act was passed which was the first step toward a true policy for the forests of the nation. The first step toward national forestry is control of the national forests. This act, whose chief purpose was to repeal the timber-culture act, contained a clause which authorized the President to reserve timber lands on the public domain, and so prevent them from passing out of the possession of the Government.

Federal Forest Reserves. - When power was given the President to make forest reserves, the public domain still contained much of the best timber in the West but it was rapidly passing into private hands. Acting upon the wise principle that forests whose preservation is necessary for the general welfare should remain in Government control, President Harrison created the first forest reserves. President Cleveland followed his example. But there was yet no systematic plan for the making or management of the reserves, which at the time were altogether without protec:tion by the Government. Toward the end of President Cleveland's second administration, therefore, the National Academy of Sciences was asked 
to appoint a commission to examine the national forest lands and report a plan for their control. The academy did so, and upon the recommendation of the National Forest Commission so appointed, President Cleveland doubled the reserve area by setting aside thirteen additional forest reserves on Washington's Birthday, 1897.

The Cleveland forest reserves awakened at once great opposition, and led to a general discussion of the forest policy. But after several years of controversy widespread approval took the place of opposition, and at present the value of the forest reserves is generally recognized.

The recommendations of the National Forest Commission for the management of the forest reserves were not acted upon by Congress, but the law of June 4, 1897, gave the Secretary of the Interior authority to protect the reserves and make them useful. The passage of this law was the first step toward a national forest service. The second step was the act of Congress, approved February 1, 1905, which transferred the control of the national forest reserves from the Department of the Interior to the Department of Agriculture. This act consolidated the Government's forest work, which had been divided between the General Land Office and the Bureau of Forestry, and secured for the reserves the supervision of trained foresters.

President McKinley, and after him President Roosevelt, continued to make forest reserves or national forests as they were later called. The latter introduced a system of examining the proposed national forests so that now their boundaries are better located than ever before. During the past few years great progress has been made by the Government in bringing about the practice of forestry by forest owners, and in awakening the great lumber interests, as well as the people in general, to the dangers of forest destruction.

The national forests lie chiefly in high mountain regions. They are 163 in number, and cover an area (June 30,1914 ) of about $164,000,000$ acres. They are useful, first of all, to protect the drainage basins of streams used for irrigation, and especially the watersheds of the great irrigation works which the Government is constructing under the reclamation law, which was passed in 1902. This is their most important use. Secondly, they supply grass and other forage for many thousands of grazing animals during the summer, when the lower ranges on the plains and deserts are barren and dry. Lastly, they furnish a permanent supply of wood for the use of settlers, miners, lumbermen and other citizens. This is at present the least important use of the reserves, but it will be of greater consequence hereafter. The best way for the Government to promote each of these three great uses is to protect the national forests from fire.

State Forestry.-Many of the states have taken great and effective interest in forestry. Among those which have made most progress are New York and Pennsylvania. New York has a state forest reserve of 3,300,000 acres, and Pennsylvania one of 945,000 acres. Michigan, Minnesota, and other states, are following their example.

The first professional foresters in the United States were obliged to go abroad for their training, but in 1898 professional forest schools were established at Cornell University, in New York, and at Biltmore, in North Carolina, and they were followed by the Yale Forest School in 1900. Cthers have sprung up since. At present, thorough and efficient training in professional forestry can be had in the United States. 


\section{Reforestation}

\section{How to Establish a Forest}

Sowing Seed. The lowest initial cost is found when seeds are sown on the ground, yet neither that method nor planting the seeds in prepared spots gives good results. Birds, mice, dry weather, and many adverse influences make it advisable to start with sturdy young trees.

Best to Plant Small Trees. By far the best plan is to purchase small seedlings or transplants, and be careful to obtain them from a reliable nursery specializing in this line. Evergreens in particular, require much skill to grow successfully.

Preparing the Ground. Though trees undoubtedly grow better when planted in worked fertilized soil, the

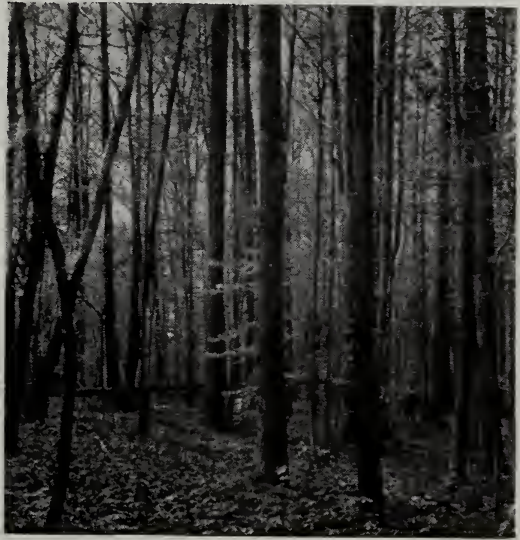
practice is to omit everything of the kind on account of its cost. If the ground is very weedy or covered with brush, it may be mowed and burned over; that is all.

Size of Trees. There is no economy in large trees; the only advantage they possess is that the plantation shows sooner. On the other hand very small trees are handicapped by the weeds. A safe rule is to use plants about a foot high. Deciduous species may be larger, evergreens smaller.

Varieties to Plant for Sperial Purposes. The owner should first decide what kind of material he desires and can produce; whether he wants to grow. hardwood or evergreen species. Market conditions, particular use, and soil will be controlling factors. The kind of tree being selected, the next questions are size or age necessary to use, where they can be procured, the time to plant and how to set them out.

In the following table an attempt has been made to group the several species which are generally adopted for planting in northeastern states and the purposes for which their wood may be used.

\begin{tabular}{|c|c|c|c|c|}
\hline Posts & Poles & TIES & PulP & LUMBER \\
\hline $\begin{array}{l}\text { Black Locust } \\
\text { Am. Arbor Vitæ } \\
\text { Scotch Pine } \\
\text { European Larch }\end{array}$ & $\begin{array}{l}\text { Black Locust } \\
\text { Am. Arbor Vitæ } \\
\text { Scotç Pine } \\
\text { European Larch }\end{array}$ & $\begin{array}{l}\text { Red Pine } \\
\text { Am. Arbor Vitæ } \\
\text { Scotch Pine } \\
\text { European Larch } \\
\text { Red Oak } \\
\text { Black Locust }\end{array}$ & $\begin{array}{l}\text { Carolina } \\
\text { Poplar } \\
\text { Norway } \\
\text { Spruce }\end{array}$ & $\begin{array}{l}\text { White Pine } \\
\text { Red Pine } \\
\text { Norway Spruce } \\
\text { White Ash } \\
\text { Red Oak } \\
\text { European Larch } \\
\text { Carolina } \\
\text { Poplar }\end{array}$ \\
\hline
\end{tabular}


There are in most instances other uses for these woods. The purpose of the above classification is to indicate general purposes for which these several kinds of wood may be used.

Varieties Best Adapted to Certain Soils. The species having been selected as to use which the owner demands, the next consideration is selecting one or more of the species, which is adapted to the soil where he desires to plant. An attempt has been made to classify in the following table the above mentioned trees according to their soil requirements. It is conceded that the better the quality of soil the more productive the tree growth, but reforesting is not as a rule considered for agricultural land. The selection, therefore, becomes a question of what is the poorest quality of soil upon which trees may be planted and there make a profitable growth. The following table indicates generally the minimum soil requirements of trees.

\begin{tabular}{|c|c|c|c|c|c|}
\hline Light SAND & $\begin{array}{l}\text { Coarse } \\
\text { Gravel }\end{array}$ & SANDY Loam & LoAM & $\begin{array}{c}\text { Good } \\
\text { SoIL }\end{array}$ & $\begin{array}{r}\text { WET } \\
\text { LANDS }\end{array}$ \\
\hline$\overline{\text { Scotch Pine }}$ & $\begin{array}{l}\text { Red Pine } \\
\text { Black Locus }\end{array}$ & $\begin{array}{l}\text { Red Pine } \\
\text { Black Locust } \\
\text { Carolina Poplar } \\
\text { European Larch } \\
\text { Am. Arbor Vitæ } \\
\text { Red Oak }\end{array}$ & $\begin{array}{l}\text { Red Oak } \\
\text { Am. Arbor Vitæ } \\
\text { Europ. Larch } \\
\text { White Ash } \\
\text { Car. Poplar } \\
\text { Spruce } \\
\text { Norway } \\
\text { White Pine }\end{array}$ & \begin{tabular}{|l} 
White \\
Pine \\
Norway \\
Spruce \\
White \\
Ash \\
Europ. \\
Larch
\end{tabular} & $\begin{array}{l}\text { Balsam } \\
\text { Am. } \\
\text { Arbor } \\
\text { Vitz } \\
\text { Basket } \\
\text { Willow }\end{array}$ \\
\hline
\end{tabular}

Time to Plant. Trees should be planted when the growth is dormant and work can be done. Such seasons are during the spring after the frost is "out of the ground" and before the season's growth begins, also during the autumn after growth has ceased, and sufficiently long before the ground freezes to permit the soil to become firm. The exact time will vary with season and parts of the State, but will be approximately April 10-May 10 and Sept. 10-Oct. 15. The advantage of season is difficult to forecast. The weather following planting will largely govern the success of the planting, other factors equal. Dry soil or drought is very injurious. Dry summers are as likely to follow as is a dry fall. Spring seasons usually have more rainy weather, and thus greater loss of time. Fall planting offers other inducements. Labor is more plentiful, work less pressing and men can be boarded for less cost. Spring planting has been more popular, but fall planting has on an average been very successful.

How to Plant. The actual work of planting is simple and can be done successfully and readily by any one. When the trees are received, they should at once be taken to the planting field, unpacked and "heeled in". The latter process consists of digging a trench, the width of a shovel and depth half the height of the trees, into which the trees are placed roots down and packed solid. They should be well watered and may be thus stored for a week or more, but should be planted as soon as possible. The planting is best done by two men, one with a grub hoe to make holes, the other with a pail of trees, do the planting. The trees should be set approximately six feet apart, each way, but judgment should be exercised in selecting the best soil or spot within a reasonable distance. The hole should be deep enough to permit the roots to lie in a normal 
position and the trees to be set at the same depth as before. The man who digs the holes should leave the dirt at the side of the hole and in as accessible position as possible in order to assist the planter. The planter takes a tree from the pail one at a time, places it in the hole and packs the soil around the roots, endeavoring to get the roots in a normal position. When all the soil is returned and the hole filled the earth is firmed by the foot, but care should be taken not to bark the tree. This operation should continue until the planting is done. As many pairs of men as are necessary may be employed. Care should be taken to see that roots of evergreen trees never become dry. The rate of planting will depend upon the efficiency of the labor; the soil and vegetation where the work is done. Planting six feet apart each way requires about 1200 trees per acre. Two good men should, where soil is not heavy, set out about an acre per day.

Preparation of soil is not necessary but the plantation must be protected from fire and grazing prohibited.

Subsequent Care. A forest plantation ordinarily needs no cultivation or special care. Fires must be kept out, of course, and stock also, but no expense for culture is warranted unless more than the economic production of lumber is involved.

Cutting Back. An exception to this rule is made when the growth of deciduous trees is slow. If each tree is cut off just above the ground the succeeding shoot is stronger and ultimately taller than the original would have been.

Replacement. If as many as 30 per cent of the trees die the gaps should be filled within two years. If the loss is less, and is fairly well distributed. filling is ordinarily not done.

Cleaning. When a plantation is five or ten years old, sometimes earlier, it may be necessary to go through it and cut out brush, tree weeds and other undesirables. This should be done always, and only, when such growth interferes $w i^{t} h$ the free development unwards of the Dlanted trees. Keep the crowns of the young trees free to the sunlight; let lowgrowing brush and weeds alone. They stimulate height growth and shade the ground.

Thinning. No plantation made as here directed will need thinning before it is twenty years old. When the time for that comes further advice should be sought.

Grazing-Fire. Grazing animals should be rigorously excluded from all tree plantations. Even if the trees are too large to be broken off or much bent, every branch within reach will be browsed. and the desirable forest conditions of shade, undergrowth, and litter will be destroyed. In a well-established grove stock may do little harm, but until the crowns of the trees are entirely out of reach cattle should not be admitted. Even then injury may result from the trampling of the soil. A heavy soil becomes packed so that it is nearly impervious to water, while a sandy one is worn and blown away, learing the roots exposed. The damage to large trees in situations where moisture is abundant is not usually great, and the protection furnished to stock in such a case may more than offset the slight injury to the trees.

Every tree plantation needs to be protected by some form of fireguard. Where conditions permit, a very satisfactory guard is made by plowing two or three furrows about the plantation close to the trees, and then making a second series of furrows from one to two rods outside the first. These lines may be kept free from vegetation by replowing each 
year, or they may be used for crops that do not easily burn. The space between the two series of furrows should be kept free of all combustible material by burning it over at safe times.

Keep fire out from among the trees themselves, except for certain times and places when you can be present during the entire burning. The times when fire is desirable are to consume brush from trimming. The limbs, dead trees, etc., should be piled where the direct heat or hot air will not hurt living trees, then burned on a day when surface litter is too damp to burn. Never allow fire to run through a forest of any age, because it will destroy the leaf-mulch that almost is the life of the forest.

\section{General Suggestions}

Advisability of Forest Planting. While the need for tree planting has not been felt in New England and the lake states as keenly as in the treeless West, large areas of land within this region are fit only for forest growth. From an economic standpoint, it is important that these lands should be put into a state of productiveness. Extensive forest planting has thus far been somewhat discouraging by present methods of taxation, and in part of the region by the difficulty in securing adequate protection from fire. The true value of forest land and its rightful place among the permanent resources of the state are, however, becoming recognized, and ar enlightened public sentiment is rapidly making this form of investment safe and profitable.

Watershed Planting. This is a problem which deserves the careful consideration of every water company having waste or idle lands. Forests on the watershed purify the water, regulate the flow, prevent erosion, and hence turbidity, and cool and shade the streams, besides converting the barrens into attractive woodlands, which eventually can be lumbered at a profit on the whole investment.

Many large town and cities store their water supply in lakes or reservoirs. Streams from bare watersheds flow in muddy torrents. Floods occur in the spring, and the water soon becomes exhausted in time of drought. As a result, there is likely to follow not only a water-famine. but also an epidemic of disease, the germs of which find perfect conditions for development in the stagnant pools that are left by the shrunken streams. After the first heavy rain, these disease germs are washed into the reservoir below, contaminating the entire water-supply. Water from slopes covered by forest is pure. Forests regulate the flow, prevent erosion and turbidity, and make waste areas beautiful and productive. Wherever natural production cannot be depended upon to cover the pastures and bare lands of reservoir watersheds with forest growth, tree planting should be practiced. While the immediate object of this forest planting will be protective, timber crops eventually will be produced which will yield good profits.

An example of practical watershed planting on a large scale may be found at Clinton, Mass., where the Metropolitan Water and Sewerage Board, under whose direction Boston and many surrounding cities are supplied with water, is planting 1,500 acres to white pine and sugar maple in mixture, under plans prepared by the Bureau of Forestry. The planting 
will be done on the old farms, pastures, and bare waste lands upon the watershed of its immense reservoir.

At New Haven, Conn., the water-table has been completely cleansed and is being treated for the production of forest both by natural reproduction and by planting.

Cut-Over Lanis. I hroughout the northeastern states and the lake region are large areas of forest land which have been lumbered and afterwards swept by successive fires. Repeated burnings have destroyed all young trees of valuabie species, and these are replaced by stands of aspen, wild red cherry, scrub oak, red maple and shrubs. Such land presents to the tree planter a difficult problem because not only will the expense of the initial planting be rather high, owing to the dense growth already on the ground, but the young trees are likely to be overcome in competition with it. Added to these difficulties is the great danger from fire. This is especially true in the lake states and Pennsylvania. The land is, however, worthless in its present condition, and where adequate fireprotection can be provided forest planting is strongly recommended.

Cut-over lands which have recently been burned, so that the growth of worthless species is checked, offer exceptionally good opportunities for planting. Lands on which sprout or seedling growth is scarce or poorly distributed may be reforested by planting the bare areas.

Worn-Out Agricultural Land. There is a large amount of land, particularly in New England and Michigan, which was cleared for farming, but which afterwards deteriorated in value, principally through loss of fertility. Throughout Massachusetts, Connecticut and New Hampshire nıany similar farms and old pastures grew up with white pine. This crop is rapidly being removed, and because no seed trees are left, little natural reproduction is taking place. Such lands, because of their nearness to market and their freedom from brush cover, offer exceptionally fine opportunities for forest planting.

Sand Dunes and Barrens. There are large areas of barren sand plains, notably in Connecticut, Rhode Island, New Hampshire, Massachusetts, New Jersey and Michigan, which cannot be tilled, and which are a source of expense to their owners. These sandy lands are suited to the requiremients of several hardy conifers, and, in many instances, will even support a good growth of white pine. As in the case of sand dunes, the problem is not of purely commercial planting, but of preventing drifting sand from encroaching on valuable property.

The Woodlot. Nearly every farm has at least a few acres which are of little value for growing agricultural crops. This land should be set aside for a woodlot and devoted to the production of fuel, fence-posts, and timber for farm uses. Large open spaces in existing woodlots can be restocked with valuable species, thus making every part of the land productive. This is best done on lands from which the trees have been cut recently. In addition to producing wood material. the farm wood-lot may, in some instances, be made to serve as a shelter-belt to protect the buildings or orchards from wind and snow.

Insect Protection. Plantations should be carefully watched to detect the presence of injurious insects. Insect damage should be reported promptly, and specimens of insects which attack the seedlings should be mailed to the Bureau of Entomology of the United States Department of Igriculture, which will identify them and suggest measures for their control. 


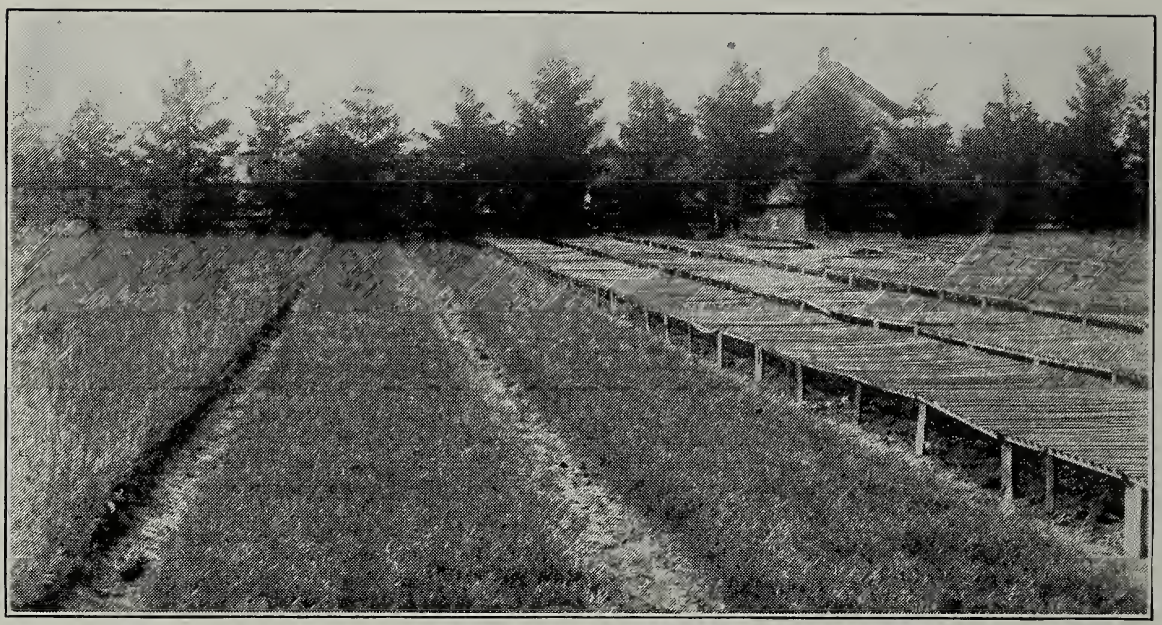

SEEDLING BEDS IN HILL NURSERY

\section{Descriptions of Varieties}

In the following pages we shall describe the more important species as regards their individual characteristics and demands on soil and situation. Apart from our recommendation, much depends on local conditions, and in most cases the planter would be well advised to call in the aid of a forestry expert, as this would enable him to avoid mistakes, which might cause his financial loss, and would relieve him of much responsibility.

\section{Evergreens (Coniferous)}

\section{ABIES BALSAMEA. Balsam Fir}

A native American variety and a handsome tree of characteristic aspect. Attains a height of 70 feet, and $2 \frac{1}{2}$ feet in diameter. The bark on all but the oldest trunks is abundantly supplied with rosin blisters which yield the Canada balsam of commerce. Thrives on bottom land and moist slopes. Rarely forms exclusive forests of any extent, but associates with ash, spruce, arbor vitae, beech, hemlock, etc. Its wood, a cubic foot of which when absolutely dry weighs only $23.80 \mathrm{lbs}$., is used for making boxes and in the manufacture of paper, etc.

ABIES CONCOLOR. Concolor $\cdot$ Fir

A variety that should be scattered through plantations in order to enhance their beauty. Its requirements are almost identical with the Douglas Fir.

\section{ABIES (TSUGA) CANADENSIS. Hemlock}

An American species-well known and appreciated. Grows to height of 80 feet with diameter of 3 feet. It was once one of the most abundant trees of the northeastern forest. Thrives best on light alluvial loam, well 
drained, cool and moist situations, usually in company with white pine, maples, etc. The wood is soft and brittle; a cubic foot weighs 26.42 pounds, and is mainly used for coarse lumber for general construction purposes. The bark of this tree is used for tanning purposes, and, until recent advances in the price of lumber, was considered its chief point of value.

\section{ABIES DOUGLASSI. Douglas Fir}

Douglas Fir perhaps may be considered as among the most important of American woods. Though in point of production it ranks second to yellow pine, its rapid growth in the Pacific coast forests, its comparatively wide distribution, and the great variety of uses to which its wood can be put, place it first. It is extensively used in the building trades; by the railroads in the form of ties, piling, car and bridge material, and by many of the manufacturing industries of the country. As a structural timber it is not surpassed, and probably it is most widely used and known in this capacity. It is particularly adapted for medium and better-class soils, which may be regarded as too good for ordinary pines and firs, and yet not sufficiently fertile for the growth of oak, etc. The root-system of the Douglas Fir adapts itself to its situation, striking down deeply or remaining near the surface, according to soil. In comparison, a plantation of Douglas Fir growing beside one of spruce, the Fir has yielded twice the volume of timber. As regards its demands upon light and heat the Douglas Fir requires more of both for its best development.

\section{LARIX EUROPEA. European Larch}

The European Larch is a deciduous conifer, similar in form and size to our native tamarack. The good qualities of the Larch have been proved by long experience, and it is now looked upon by many as almost a native tree. It affords excellent material for fencing when young and for building purposes when older.

The soil most suitable for this tree is a fresh, friable, loamy sand or clay, that is not too stiff. The presence of stones is no disadvantage.

It is especially suitable for mixture in deciduous and coniferous plantations. The high quality of its timber causes it to be much sought after and to command good prices.

Sunny sheltered situations facing south are well adapted for the Larch; on the other hand. it should not be planted on poor dry soil or in extensive woods without the admixture of other species which can exercise a protective influence upon the soil. In the United States, plantations have been made from New England to South Dakota. The exact limits of the regions in which planting is advisable can not be given, but it is evident that commercial plantations may be established throughout the northeastern states, and westward through the central and lake states to South Dakota and the prairie region. In Iowa, eastern Kansas and Nebraska, European Larch is, when planted in suitable situations amnns the most promising of our conifers.

In the prairie region, plantations of European Larch should be thorolighly cultivated until the trees are able to compete successfully with encroaching grasses. In the East, cultivation after planting is not required.

Examinations of Larch plantations in Illinois, Iowa and eastern Dakota has shown that the annual financial returns per acre were approximately as great as from field crops properly managed, and the plantation required less care. 


\section{PICEA CANADENSIS ALBA. White Spruce}

A variety of exceptional hardiness, growing extensively in the northern portion of the United States. In some cases it attains a height of 150 feet but more often it is 50 to 75 , with straight trunks 3 to 4 feet in diameter. It is one of the most useful trees in windbreaks in exposed situations, and should be used in spite of the fact that the timber is not specially valuable.

\section{PICEA CANADENSIS. Black Hills Spruce}

Simply another form of the American White Spruce, with same characteristics, and if anything, more hardy. Grows very compact, and its foliage has a somewhat bluish sheen. A valuable species for planting in the northwestern states, and a type that will be planted more widely as it becomes better known.

\section{PICEA EXCELSA. Norway Spruce}

A variety introduced from Europe and a most indispensable tree for many situations, especially mountain districts, uplands, etc. In fact, it is widely planted with entire success all over the country. As it has no táp-root, but extensive lateral roots instead, it can maintain itself in shallow soils and rocky and stony ground. Owing to the shade which it casts and to the abundance of humus formed by fallen needles, it has a beneficial effect on the soil. It need not be confined to hills, but may be successfully planted on level land that is sufficiently moist, where it is capable of yielding a handsome return.

Its uses are manifold; it serves as a protection against wind; it may be planted in groups on fresher soils in large pine woods where it affords welcome shelter for game, etc. It makes an especially good pheasant cover owing to the density of its foliage.

\section{PICEA PUNGENS. Colorado Blue Spruce}

This tree is a native of the Rocky Mountains. It is very hardy and well suited for positions which are too damp for the common spruce. Owing to the beauty of its foliage it is highly ornamental as a park tree.

Although it is easily satisfied as regards soil, care should be taken that good earth is placed about its roots at the time of planting. It prefers open positions and generally occurs in mixed woods. In its natural habitat it grows at elevations up to 8,000 to 10,000 feet above sea level.

\section{PINUS AUSTRIACA. Austrian Pine}

This tree somewhat resembles the Pinus Sylvestris, but it may be distinguished from the latter by its needles, which are long, rigid and dark green. In open positions, a broad bushy crown is produced which has an ornamental effect. It is essentially a tree for calcareous soils, and grows satisfactorily even on the poorest of these. It is also useful in mixed plantations and is of service as a nurse or shelter tree.

PINUS BANKSIANA. Jack Pine

Jack Pine usually attains a height of from 30 to 50 feet, and a diameter of from 8 to 12 inches. Under favorable conditions a height of 90 feet and a diameter of 2 feet may be reached. It has a fairly straight and symmetrical stem, and when grown free, a low, full crown. In close stands the crown is narrow and covers only the upper part of the tree. The needles are 1 to $1 \frac{1}{2}$ inches long and grow in pairs bound by a short sheath. 
The natural range of Jack Pine is along the northern border of the United States, from eastern Maine to Minnesota. In the United States it is commonest in northern Michigan, Wisconsin and Minnesota. The tree is recommended for planting in the north central states where the soil is poor but contains moisture not far below the surface. It is one of the most rapid-growing pines. The wood is light, soft, coarse grained, moderately strong and moderately durable. It makes good coarse lumber, and when chemically treated, very satisfactory posts and ties. In most of its qualities it compares with the Loblolly Pine of the southeast. It is somewhat inferior to Red (Norway) Pine and Western Yellow Pine. Jack Pine is a good tree for windbreaks and shelter-belts, and for farm woodlots in the Dakotas, Nebraska, and throughout the sandy regions of the north central states, wherever a better tree will not thrive.

\section{PINUS FLEXILIS. Limber Pine}

Pinus Flexilis is a tree of the mountains. It is of interest to the planter, on account of the fact that it is a somewhat rarely occurring species. The cones are long, and the leaves, five of which are bunched together, vary in length from two to three inches. It is quite popular for ornamental purposes.

\section{PINUS MUGHO. Dwarf Mountain Pine}

A dwarf species used mainly for ornament. Its timber is certainly poor, but still the tree is not without its usefulness.

It improves the soil by the shedding of needles and thus prepares the way for more exacting species. It may be employed with good results for purposes of protection against erosion and landslides, in shelter-belts and game covers. High winds do not affect it.

\section{PINUS PONDEROSA. Bull Pine}

This is the Western Yellow Pine and is one of the largest and most valuable of the pines. It ranges in size from not more than 60 feet high in the arid portions of its range to 200 feet in height and 6 feet in diameter on the western slopes of the Sierras. It has a straight and symmetrical stem and usually a long, spire-like head, which, even in fairly dense stands, covers from one-half to one-third of the tree. The needles are from 6 to 10 inches long and usually grow in clusters of three.

The natural range of Western Yellow Pine is throughout the United States west of the one hundredth meridian. It is most common in the Rocky mountains and Pacific coast ranges at medium altitudes, and in the Black Hills region.

The tree may be planted anywhere within its natural range, and in favorable situations several degrees farther east. It is particularly well suited for planting in the sandhill regions of western Nebraska and Kansas and on denuded watersheds in the Rocky mountains and Pacific coast regions below an elevation of 6,000 feet.

The wood, which is light, strong, dense, and moderately durable, is the most valuable one of the Rocky Mountains and the most extensively used. Because of its dense foliage the tree forms excellent watershed cover. It is quite intolerant of shade.

\section{PINUS RESINOSA. Red or Norway Pine}

Red Pine may be planted on situations similar to those recommended for white pine. In form and rapidity of growth it is very similar to the white pine and because of its freedom from insect injury may sometimes 
profitably be substituted for it. The wood is valuable for all kinds of house lumber, and when chemically treated makes good posts and ties. It is somewhat stronger than white pine, and in the coal regions it is valuable for mine props.

This variety is well adapted to pure plantations, but it may be mixed with European larch, chestnut, red oak and sugar maple. The tree is very light demanding, and it is essential that associated species should not suppress it. To prevent this the other species should, in general, be of slower growth. European larch, however, though it grows faster than Red Pine, is a very desirable tree in mixture, since its crown casts little shade. When planted with Red Pine, it should never exceed a proportion of one to three in the plantation. In all other mixtures Red Pine and the associated species should be planted alternately so that Red Pine will make up half the stand.

\section{PINUS STROBUS. White Pine}

The White Pine is the largest of all conifers indigenous to the eastern part of the United States. On proper soil it may reach the age of 250 years or more, and attain a height of 150 to $175 \mathrm{feet}$, and a diameter of 3 to 5 feet. The crowns of mature White Pines in mixed forests conspicuously overtop the surrounding hardwoods. Mature forest-grown trees are characterized by straight, columnar trunks, destitute of branches for a distance of 75 to 100 feet from the ground, and thin, irregular crowns. At the base of the trunks of old trees the bark is thick and deeply furrowed and of a dark brown color, but becomes thinner and grayish toward the upper part of the tree.

The northern boundary of the natural range of White Pine is from Newfoundland west to eastern Manitoba. Through the lake region the range extends west to eastern Minnesota and south to northern Iowa, Indiana, Illinois and Ohio. In the East it originally occured throughout New England and the Middle states, and, on the higher elevations of the Appalachians southward to Georgia, and Alabama. It was found in greatest abundance and reached its best development in the St. Lawrence valley and the lake region. It usually grows in association with hardwoods and other conifers, and reaches its largest size in mixture with the former.

Much of the abandoned agricultural land in New England may be profitably planted with this tree, which can be recommended for reforesting burned and cut-over areas generally throughout its economic planting-range.

White Pine grows naturally and best in a cool climate on a fresh, light, deep and sandy soil with a porous subsoil. It readily adapts itself to both dry and moist soils, for it is found on the poorest and driest sand, and on steep, rocky slopes, and also on moist clay flats and river bottoms, provided the latter are not continuously wet. It is capable of disputing possession with hardwoods, even on fresh, medium-heavy clay and loam soils. It will endure windy and cold exposures, but should not be planted near the seacoast, since it cannot withstand strong sea breezes.

White Pine can endure considerable shade for a number of years, but as it becomes older it requires more and more light for its development, and after it is forty or fifty years o!d the crown demands full sumlight. On this account White Pine is best grown in mixture with slower-growing hardwoods or other conifers which will not overtop or shade it from above.

The wood of White Pine is soft, light, straight grained, and easily worked, and will not warp. It was formerly used to a great extent for 
general construction, but on account of its growing scarcity and high price it has been largely superseded for this purpose by other woods. The better grades of this lumber are still used in naval construction-for decking. interior finishing and spars. Throughout the manufacturing regions of New England, wherever there is a market for small material, Thite Pine will prove the most profitable conifer that can be grown on poor soils.

In pure plantations White Pine produces excellent forest conditions, but it is also adapted to growth with a number of other species of which chestnut, European larch, Norway spruce, red oak and hard maple are the more important. Chestnut is a rery desirable tree for mixture with White Pine on well-drained soils which are not calcareous, but since the planting range of chestnut does not, except in Vermont and New Hampshire, extend above the forty-second degree of latitude, it cannot be used in mixture except within a limited area. In Pennsylvania, Michigan, IVisconsin, Minnesota and northern New York. White Pine may be mixed with European larch, Norway spruce, or hard maple, and on soils adapted to red oak the latter may be used to advantage.

\section{PINUS SYLVESTRIS. Scotch Pine}

The Scotch Pine closely resembles the red pine of North America. In Europe, in the region of its best development, it commonly attains a height of 120 feet and a diameter of from 3 to 5 feet. For a considerable distance above the ground the stem is comparatively smooth and free from branches. In the forest the crown is short and compact, extending not more than one third the length of the bole. The bark is usually deeply furrowed and, on the upper portion of the trunk, is distinctly reddish in color.

In this country Scotch Pine does not occur naturally. Abroad it is widely distributed, ranging throughout the greater part of Europe and through northern Asia southward to Asia Minor and Persia. In the region Jf its natural distribution extensive planting has greatly increased its occurrence, until at present it is probably the most important forest tree in Europe.

In the United States, Scotch Pine can be planted over a wide area, including New England, the middle and lake states, the Dakotas, arid especially the prairie states, such as Nebraska, Iowa and Kansas. The ab:lity of this tree to thrive in situations where the atmosphere is exceedingly dry admirably adapts it to the prairie states.

Although inferior in many respects to our white pine, the Scotch Pinc will form an excellent substitute, and its great hardiness commends it for wide planting in the United States. It is well suited for windbreaks and shelter-belts and has already been so used in the Middle West.

\section{THUYA OCCIDENTALIS. American Arbor Vitae}

Arbor Vita is planted extensively for evergreen hedges as it retains its lower limbs. It will not do well on the dry open prairies as it is a surfacerooted tree. This variety transplants easily. If planted at all, a wellsheltered situation and moist soil should be given if possible. Grows naturally from Nora Scotia and Manitoba to North Carolina and Illinois.

The foliage is bright green, yellow-green beneath, or in winter assuming tcnes of brown and bronze. There is no evergreen, either native or introduced, which will endure as much hardship and grow on as great a variety of soils, under even adverse conditions, as the Arbor Vitæ. 


\section{Deciduous Trees (Leaf Bearing)}

\section{ACER SACCHARUM. Hard or Sugar Maple}

The Sugar Maple is a large, heavy-crowned forest tree of symmetrical form. In favorable situations in New England, New York, and the Appalachian mountains it sometimes reaches a height of 120 feet and a diameter of from 4 to 6 feet, with a trunk clear of branches for 70 feet. The average height is about 80 feet, with a diameter of 3 feet.

When growing in the open the trunk divides about 10 feet from the ground, into several large branches, which spread into a broad, roundtopped head.

Sugar Maple is widely distributed in the eastern United States. Its natural range is from southern Newfoundland to northern Georgia and western Florida, and west to Minnesota, eastern Nebraska, eastern Kansas and eastern Texas. It is most abundant in Minnesota, Wisconsin, Michigan, New York and Maine, and on the Appalachian slopes.

It is a somewhat slow-growing, long-lived tree, and develops much more slowly than the other Maples up to the fifth year. Plantations of this species, however, make an average height growth of over 1 foot per year during the first thirty or forty years, but after that the rate decreases.

The wood of Sugar Maple is heavy, strong, dense, and very hard, but not durable in contact with the soil. It is susceptible of fine polish and is used in large quantities for interior finish, floors, musical instruments, furniture, woodenware, vehicles, cooperage and novelties. The wood stands alternate wetting and drying well, and is therefore one of the best for the manufacture of washing-machines. "Curly" and bird's eye" maple, obtained from this species, are desirable for finishing and cabinet work. The wood makes charcoal of unsurpassed quality, is a source of wood alcohol, and has a very high fuel value.

The chief value of Sugar Maple for economic planting is as a sugarproducer. The sap contains from 2 to 6 per cent of sugar. Three to 9 per cent of the total sap-content of the tree may be utilized for sugar-making without dangerously lessening the tree's vitality.

Sugar Maple is well adapted for planting as a filler with some lightdemanding species, and its tolerance and heavy crown make it one of the best species available for underplanting in open forest or plantation to protect the soil.

It grows equally well in pure stands and in mixture with any of its natural associates. Species with which it may be planted to advantage are white pine, red pine, white oak, red oak, shagbark hickory, white elm, chestnut, and basswood. The Maple should be planted pure only when it is desired to establish a sugar orchard.

\section{ACER SACCHARINUM. Soft Maple}

The Soft Maple grows rapidly, attains a large size, and is rather shortlived. It is among the first trees to come into leaf in the spring, but loses its foliage rather early in the fall. Since the wood is brittle, the branches are easily broken by the wind. It grows naturally with many other hardwoods. This variety is not generally suitable for upland situations, and efforts to establish plantations in the middle western states have usually met with failure. In the west it succeeds only where the roots can go down to permanent water.

It is moderately tolerant; on good situations it approaches the sugar 
maple in shade-enduring qualities, while on the upland it can be classed as almost intolerant. It is advisable to grow Soft Maple in mixture with some ground-shading species, since its crown is too light to keep out grass and weeds. Upon moist soils, if not planted pure, it may be mixed with walnut, catalpa, white ash, or black cherry.

It is valuable chiefly as a quick-growing shelterbelt tree and for fuel. The wood is too inferior to make the planting of the species profitable for any other purpose.

\section{BETULA ALBA. White Birch}

In this tree are combined quite a number of admirable qualities which commend it under certain circumstances for use in the forest. Still one should avoid establishing pure forests of Birch, as the tree is incapable of protecting the soil. The Birch is one of the least exacting species. It suits practically all kinds of soils, heavy clay, as well as light sand soils, wet and dry situations, when standing alone or crowded closely in dense cover. The Birch is well adapted for the filling in of blanks in coniferous woods, and as an occasional tree in plantation. As a protection against forest fires it has a distinct value, when several rows of it are planted beside roads and on railway banks. In such position with its silvery bark and the light green foliage, the Birch affords the first manifestation of spring and contributes considerably to the beauty of the woods. The graceful habit and picturesque trunk make the Birch a conspicuous object. 'The trees are hardy and especially valuable in cold climates.

\section{CASTANEA AMERICANA. American Sweet Chestnut}

Chestnut is among the largest of our valuable trees, and in the region of its best development has been known to reach a height of 120 feet and a diameter of great size.

It is distributed throughout the eastern part of the United States at elevations varying from sea-level in Massachusetts to 5,000 feet in North Carolina. It ranges from southern Maine southward through New England, but in this region is most abundant in the lower valleys of the Merrimac and Connecticut rivers. Except near the sea, it is common in Rhode Island and Connecticut, and as far south as Delaware. It is found also in the province of Ontario and in the eastern states, especially in New Jersey, Pennsylvania, and parts of Maryland. Further south it is found along the Appalachians to Alabama, growing well in all soils above 2,000 feet in elevation, but less abundantly below. In the Middle West it is confined to Michigan, Indiana and Illinois.

Large areas throughout the East, particularly in New England, New York, Pennsylvania and Maryland, are well adapted to Chestnut.

Chestnut will thrive on a variety of soils, from almost pure sand to coarse gravels and shales. On limestone soils, however, it usually does not make good growth. In general it prefers the dry, well-drained, rocky land of the glacial drift to the richer, more compact alluvial soil of the lowlands. Chestnut does not need a rich soil so much as one whose physical structure insures good drainage. Light is essential to the tree, since it is somewhat intolerant of shade.

Chestnut timber is in great demand. The wood is light, moderately strong, coarse grained. and elastic. It works easily and is very durable in contact with the soil. In seasoning, the wood often checks and warps, but damage from this source is not serious. It is used in cabinet work and cooperage, and for fence-posts, telegraph and telephone poles; ties, and mine-timbers. The presence of tannin in the wood increased the de- 
mand for small sized and inferior material, and large quantities are used in the manufacture of tanning extracts. It is not advisable at present to start plantations of chestnut as there has lately been serious development of chestnut blight in chestnut stands and no practical method of combating this disease has been devised.

\section{CATALPA SPECIOSA. Hardy Catalpa}

Hardy catalpa is a tree of medium size, with slender branches forming a spreading, round-topped head. Under average conditions it grows to be from 50 to 70 feet high. In the forest it is straight and tall and occasionally attains a height of more than 100 feet and a diameter of from 2 to 4 feet.

Hardy Catalpa, in its natural range, was confined to a very limited region, extending from the valley of the Vermilion river, in Illinois, through southern Illinois and Indiana, western Kentucky and Tennessee, southeastern Missouri, and northeastern Arkansas. It was apparently distributed by backwaters along the overflow lands of the Wabash river, up nearby creeks, and down the Ohio and Mississippi Rivers as far as New Madrid, Mo. In southeastern Missouri it meets the common Catalpa (Catalpa catalpa).. The latter species is indigenous to southwestern Georgia, western Florida, central Alabama and Mississippi, but is widely naturalized and cultivated east of the Rocky mountains, growing as far north as eastern $\cdot$ New England.

The Hardy Catalpa has been planted as far north as Turner county in South Dakota, southern Minnesota, southern Michigan and southern Massachusetts, and westward to eastern Nebraska, central Kansas, and central Oklahoma. It has done well on irrigated lands in New Mexico, Colorado and Utah, at the lower altitudes, and where the soil is free from alkali. The present range for economic planting is on the fertile alluvial lands of the Middle West. Catalpa plantations have been especially successful in the southern portion of Ohio, Illinois, and Indiana; in Nebraska, south of the Platte river and east of Adams county, and in eastern Kansas.

The Hardy Catalpa matures early and under cultivation is one of the most rapid-growing trees planted in the West. A height growth of $2 \mathrm{~T} / 2$ feet and a diameter increase of one half inch annually for the first ten or fifteen years are not unusual. It requires a very good soil, one which will grow good corn, to make a rapid growth.

Some of the trees in a plantation will be of suitable size for posts when from 8 to 10 years old, and five or six years later the entire crop should become merchantable. Good telegraph poles are grown in from twelve to twenty years, according to the adaptability of the soil for this species.

The rapid growth, durability in contact with the soil, lightness, elasticity, and high fuel value of Catalpa wood make the tree one of the most valuable for economic planting. Catalpa wood cut from the living tree is probably immune from attack by fungous diseases, and is one of the most durable timbers known. When used for fence posts it has been known to remain sound for thirty to forty years. Even in young trees, nearly $7 \mathrm{~b}$ per cent of the wood is heartwood, so that when used for posts the decay of the sapwood does not materially affect the value of the post. The rich coloring of the wood makes it also well suited for cabinet work.

It is usually advisable to cultivate plantations during the first three seasons, although in regions of abundant rainfall they may be planted with 
cowpeas or soy beans, or sown to crimson clover after a season's cultivation.

\section{FRAXINUS AMERICANA. White Ash}

In the forest, White Ash is a tall, slender tree with a smooth trunk, which is surmounted by a small, open crown of stout, upright branches. The trunk is often free from branches for more than half its leng:?. In the open the trunk usually divides a few feet above the ground into several main branches, which form a graceful, rounded head, rather open and widest near the base. On the bottom-lands of the lower Ohio valley, where the best development is attained, White Ash cccasionally reaches a height of 100 feet, though in general it is a tree of medium size, with an average height of from 70 to 80 feet and a diameter of from 2 to 3 ? The roots penetrate deeply into loose soil but where hindered by rocks or an impenetrable substratum they develop an extensive lateral system.

The natural distribution of White Ash is from Nova Scotia and New Foundland to northern Florida, central Alabama and Mississippi, and westward to Ontario, northern Minnesota, eastern Nebraska, Kansas, Oklahoma and Texas. It seldom occurs in large masses, but usually as single specimens among the common hardwoods, such as the maples, elms, bass wood, birches, walnuts and oaks.

The range for economic planting is from the valley of the Wabash and Ohio river north and west through Indiana and Illinois to the region of the Great Lakes; westward through Iowa, southern Minnesota, and eastern South Dakota; southward through eastern Nebraska and Kansas into northern Oklahoma. White Ash will undoubtedly prove a valuable tree for planting in the arid regions on irrigated lands now being opened for settlement.

\section{FAGUS AMERICANA. American Beech}

The most distinct of our Eastern America forests. It sometimes surpasses 100 feet in height with straight, columnar trunk 3 to 4 feet in thickness vested in its smooth, bluish gray bark. It usually inhabits rich, well-drained uplands and slopes, in company with hard maple, birches, hemlock, etc. Grows very slowly and is of too low value for commercial planting. It is a beautiful tree at all times, each successive season of the year giving to it a peculiar charm.

\section{HICORIA OVATA. Shagbark Hickory}

The Shagbark Hickory is a forest tree which commonly attains a height of 70 to 80 feet and a diameter of about 2 feet. Under favorable conditions, a height of 120 feet and a diameter of 4 feet is reached. When grown free, the stem often branches near the base and the crown becomes full, though it always remains narrow; in the forest, the crown is short and small, while the stem frequently has a clear length of from 50 to 60 feet.

The natural range is from southern Maine west through southern Michigan to eastern Kansas, Nebraska, Texas, and south along the Appalachian mountains to Florida, Alabama and Mississippi. It reaches its best development on the western slopes of the Appalachians and in the regions drained by the tributaries of the Ohio River.

The Shagbark Hickory is generally found in mixture with other trees, although pure stands are not rare. Its principal associates, besides other hickories, are the oaks, maples, ashes, chestnut, basswood and yellow poplar. 
The tree is recommended for planting on good soil in the valley of the Ohio riyer and along its tributaries in Ohio, Indiana, Illinois, Kentucky and Tennessee, and on fertile hillsides of the Appalachian mountains.

Shagbark Hickory grows best in a deep, rich, moist loam. It does well in other moderately rich soils which permit the tap-root to penetrate to a moist subsoil, and in the middle states makes good growth in comparatively well-drained situations wherever it can get the requisite amount of sunlight. It will not thrive in a hard clay soil, or in pure sand, or where a layer of hardpan lies near the surface

It is nearly as tolerant of shade as the hard maple, but like all species, grows more rapidly in full sunlight and does well only in the open or when surrounded by other trees which only slightly obstruct the light. When overshadowed, it grows very slowly. Under right conditions the rate of growth is about the same as that of White Oak.

The wood is heavy, hard, very strong, tough, flexible, but not durable in contact with the soil. It is used extensively in the manufacture of carriages and agricultural implements and for ax and tool handles. There is, in consequence, a good demand for the lumber, at a high price. Secondgrowth hickory, or that which is largely sapwood, is especially esteemed. The wood of the young sprouts is used in making baskets, barrel hoops, and other articles in which flexibility and toughness are required.

If the plantation is on tillable land, it should be cultivated until the trees become large enough to shade the ground. In any case live stock should be excluded and protection against fire should be provided for.

\section{JUGLANS NIGRA. Black Walnut}

When grown in the open, the Black Walnut is a rather symmetrical tree, with a massive crown, short trunk, and form similar to that of open-grown oaks and chestnuts. In the forest the trunk lengthens into a tall, tapering column, often with no limbs for a distance of 50 or 60 feet, and surmounted by a much-reduced crown. The foliage is thin, and never completely shades the ground. On the lower mountain slopes of the Carolinas a height of 110 feet and a diameter of from 5 to 6 feet is of ten attained. The usual height of the mature forest-grown tree is from 70 to 90 feet, and the diameter from 30 to 45 inches. Trunks of low, spreading trees in the open often measure over 6 feet in diameter.

Black Walnut is one of the most widely distributed and valuable of our deciduous trees. In nature it grows sparingly from southwestern New England westward, through New York, Ontario, Michigan and Wisconsin. to southern Minnesota, thence southward, with central Nebraska and Kansas as the western limit, to south-central Texas and Florida. It does not appear along the Gulf or the South Atlantic seaboard, and is much more abundant in the central than in the eastern states.

Although of fair size wherever found, Black Walnut attains its best development in the deep hollows of the western slope of the southern Alleghanies, on the rich bottom-lands along the Mississippi and Ohio rivers, and in Arkansas, Missouri, eastern Nebraska, Kansas and Oklahoma. In the mountains of the Carolinas and Tennessee it occurs in mixture with oaks and chestnut, while in the original hardwood forests in the river valleys of Ohio, Indiana, Illinois and Kentucky, it is found associated with the maples, hickories, oaks, basswood, cherry and other hardwoods of the region, though not always intermingling closely with them. West of the Mississippi the Walnut is confined to river valleys and moist situations. In Iowa and eastern Nebraska plantations of Black Walnut have been 
successfully made. Plantations have been made as far west as Salt Lake City; southern Idaho, and throughout California, with evident success. In California the Black Walnut has been planted to a very limited extent for timber, to a greater extent for ornament and the yield of nuts.

The ideal conditions for growth are found in the rich, moist soil of bottom-lands or on fertile hillsides which are protected from cold, sweeping winds. A calcareous soil or a sandy loam of gravel and a large quantity of humus, overlying a deep subsoil of gravel and a water-table in which the long tap-roots can find a continual supply of moisture, furnishes the best conditions for growth. The surface soil should be moist but not wet, and the subsoil porous.

In good soil the rate of growth is fairly rapid and is continued up to mature age. In the best situations planted trees occasionally make a diameter growth of nearly an inch each year, but under average conditions the increase is less.

The greatest returns will be realized from this species when it is planted with a view to growing saw timber. If a walnut plantation is established for this purpose, it is advisable to underplant with some tolerant tree that may be cut with profit, leaving the walnut as the permanent stand after the forest has reached the stage of maturity.

The plantation should be cultivated until the tops of the trees meet. During the first three years corn may be grown between the rows to give additional returns from the soil.

\section{QUERCUS ALBA. White Oak}

White Oak, when grown in the forest, is characterized by a long, clean trunk of rather uniform diameter, surmounted by a comparatively small crown. In the open the crown becomes rounded and massive, much greater in breadth than in height, supported by a short, sturdy trunk. Under average conditions the tree grows to a height of from 60 to 100 feet, with a diameter of from 2 to 4 feet.

White Oak forms pure forests and is also found in mixture with other varieties, such as chestnut, elm, basswood, hickory, maple, black walnut, red oak.

In early life it is not so vigorous as red oak. Growth is slow but persistent and trees attain great age The average annual height growth is about 8 inches. Under the more favorable conditions that usually prevail in a planted forest the rate of growth would be somewhat higher.

The wood of White Oak ranks among the best in general usefulness and is superior to that of other species of oak. It is ashy gray in color and is strong, heavy hard, tough, close-grained and very durable.

\section{QUERCUS MACROCARPA. Bur Oak}

The Bur Oak is best suited to deep, rich, river-bottom soils. It will maintain itself in poorer upland localities, but it is recommended for pianting only where the soil is fairly good, moist and well drained and where protracted droughts are infrequent. It is rather intolerant of shade and will not thrive beneath the crowns of taller trees. The rate of growth, except under the best conditions, is somewhat slow, and is about like that of the white oak. Neither grows so rapidly as the red oak. The wood is heavy, hard, very strong and durable. In the market it is not and need not be distinguished from white oak and it is used for the same purposes. 


\section{QUERCUS RUBRA. American Red Oak}

Red Oak is one of the largest trees in the forests of the Northern States. The average height of mature trees is from 70 to 90 feet and the diameter from 2 to 4 feet. The natural habitat of the tree extends over the whole hardwood district of northeast America.

Its sylvicultural advantages consist in its being comparatively unexacting in regard to soil and situation and in its quick growth. The latter quality is characteristic of the tree from its early youth. Many successful plantations of Red Oak have been established in the East, as its timber is in great demand for railroad ties, etc.

Plantations of Red Oak need very little care, except where the rainfall is so deficient that the soil must be cultivated to conserve the moisture. All that is ordinarily necessary is to see that the little trees are not smothered by grass and weeds, that stock and fire are kept out, and that the plantation acquires the character of a forest as soon as it can. Weeds and litter on the ground and shrubs that stand below the crowns of the trees are good and should not be interfered with.

\section{ROBINIA PSEUDACACIA. Black Locust}

The meagre extraordinary demands which locust makes upon the so1 and the power it has of reaching food material at a distance by means of its wide spreading root-system, account for its success in places where other trees completely fail. It is especially adapted for sandy soils of poor quality. It is a fast-growing variety and valuable for fence-posts, fuel, etc. It grows successfully from the Rocky mountains to the Atlantic coast, but in certain districts planting is partially prevented by injuries caused by the locust borers. When used in plantation, the locust may be cut back to the ground during the winter of the second year after planting. During the first season of sprout-growth one good tall sprout should be chosen and the rest cut off. In this way the tendency to irregular or crooked growth may be avoided. On account of the likelihood of destructive attacks by the locust borer the planting of black locust for commercial purposes cannot be recommended.

\section{TILIA AMERICANA. American Linden or Basswood}

The Linden or Basswood is one of the most abundant and useful trees of the eastern United States and Canada. It attains a height of 125 feet. It prefers rich, moist, but well-drained slopes and bottom-land, and is a handsome tree at all seasons. The wood is light, soft and tough, and much sought for use in carriage-building, furniture, woodenware, etc. The fibrous inner bark furnishes valuable bast for mats, cordage, etc. Does not grow very rapidly.

\section{LLMUS AMERICANA. American White Elm}

The White Elm is a forest tree which frequently attains a height of from 100 to 120 feet and a diameter of from 6 to 8 feet. Its average size is somewhat smaller although it is among the largest of our hardwood trees.

When grown in the open the trunk almost invariably divides a short distance above the base, forming a widespreading graceful crown. Forestgrown trees exhibit a wide divergence in form. The trunk is often clear of branches for over two-thirds of its length, straight and gradually tapering, surmounted by a compact crown. At the base the larger trees 
are often buttressed. The slender, interlaced twigs and the rough, flaky bark, divided into narrow ridges, are typical of the tree in all situations.

The natural distribution of White Elm is extensive. It ranges from Newfoundland to South Dakota and south through western Nebraska to Texas. The tree does not grow in pure stands, but occurs sparingly in mixture with the oaks, ashes, sycamores, yellow poplars and other hardwoods.

The planting range is fully as wide as its natural distribution. It may be planted throughout the East and is especially well suited for prairie and plain plantations.

Elm wood is strong, tough, fibrous and difficult to split, but is not durable. It is in growing demand as a slack-cooperage material, and its lise in this industry has resulted in a rapid increase in the stumpage value. The timber is also used for flooring, wheel-stock, and ship-building, and in the manufacture of agricultural implements.

The hardiness of the species and its indifference to soil conditions make it a very suitable tree for protective planting. For ornamental planting the suitability of the White Elm is everywhere recognized. It is probably the most desirable of our hardwoods for such use.

\section{Review and a Conclusion}

We have been helped materially in arriving at the opinions expressed in the foregoing pages by the published results of investigations and experi. ments carried on by the United States Forest Service and the different State Departments of Forestry as well as by information gathered from technical literature. We are greatly indebted to Mr. C. R. Pettis, Supt. New York State Forests for many suggestions and information concerning reforesting which has been of much value and assistance to us in getting out this tree manual. We are also thankful to Mr. Alfred Gaskill, State Forester, New Jersey, for the assistance given us. To the various other State and National Foresters and officials who through Bulletin and Reports are disseminating knowledge we gratefully extend our sincere thanks.

The plans which have been set forth in the preceding pages are not regarded as perfect, but they are based on considerable practical experience, and it is believed that they demonstrate beyond a doubt how far superior is a well-considered, systematic method of handling the problems of forestry, to the haphazard, careless methods so often practiced.

We have no hesitation in saying that the question of the world's timber supply will, in the near future, require very careful consideration. It is easy to see that the reckless destruction of the natural forests will entail a great scarcity of timber, and as a natural consequence, the prices for the most commonly used kinds will rapidly rise. In certain districts, it is not unlikely that a considerable portion of poor, sandy land, from which little profit is derived, may be made remunerative by being reforested; and certainly there are millions of acres of undeveloped land that it would pay the state to put under timber. Climate, soil and industrial requirements all are in favor of extensive tree-planting. 


\section{Planting Distances}

Showing the number of trees required per acre from 1 to 30 feet distance between each tree.

\section{NUMBER OF TREES OR PLANTS ON AN ACRE AT VARIOUS DISTANCES}

At 3 feet apart each way....4,761 At 12 feet apart each way....325

At 4 feet apart each way....2,729 At 15 feet apart each way....200

At 5 feet apart each way....1,742 At 18 feet apart each way....135

At 6 feet apart each way....1,200 At 20 feet apart each way....110

At 8 feet apart each way.... 680 At 25 feet apart each way.... 70

At 10 feet apart each way....440 At 30 feet apart each way.... 48

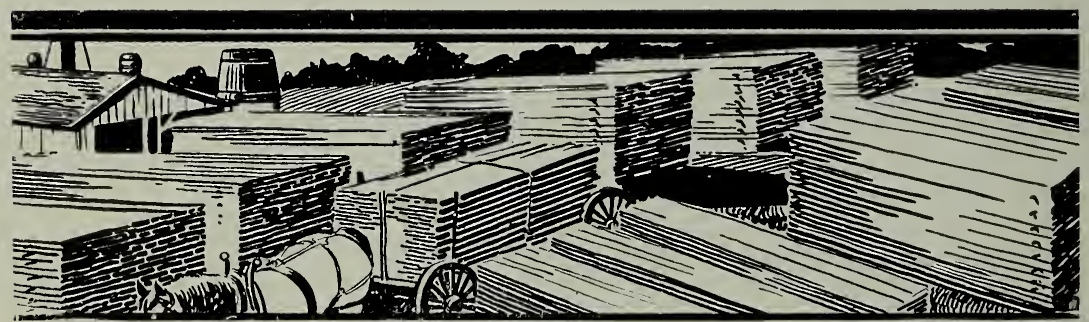




\section{THE YOUNG MAN OF TODAY}

\section{Can Get the Best Forest Training}

\section{in the Great Forests of the Upper}

Peninsula of Michigan at

Wyman's School of

\section{the Woods}

\section{DIRECTED BY}

Thos. B. Wyman, President Northern Forest Protective Munising, Michigan. Association,

D. Hill, Vice-President, President of the Dundee, Illinois.

Dr. T. W. Scholtes, $\quad$ D. Hill Niursery Co.,

Sec'y-Treasurer, Physician,

Munising, Michigan.

Wm. G. Mather, Director, President of the Cleveland Cliffs Iron Co., Cleveland, Ohio.

D. Clark Everest, Director, Manager of Marathon Paper Mills,

Wausau, Wisconsin.

Elwood Wilson, Director, Forest Engineer,

The Laurentide Co., Grand Mere, Quebec.

C. V. R.Townsend, Director, President of the Munising

Woodenware Company, Negaunee, Michigan.

A. O. Jopling, Director, Chairman, Mackinac Park Commission,

Marquette, Michigan.

J. G. King, Director,

H. A. Holden, Director, Gen. Sec. Y. M. C. A., Roslyn, Washington. Manager, Munising Pub-

lishing Company,

Munising, Michigan.

Walter W. Gleason, Director, Professor of Logging

ted

Write for Complete Catalog. Address

WYMAN'S SCHOOL OF THE WOODS MUNISING, - - - - MICHIGAN 
